\title{
Quality of Life and Level of Depressive Symptoms in the Geriatric Population
}

\author{
Geriatrik Populasyonda Yaşam Kalitesi ve Depresif Belirti Düzeyi
}

\author{
Yeşim Akyol ${ }^{1}$, Dilek Durmuş ${ }^{1}$, Cengizhan Doğan ${ }^{1}$, Yüksel Bek ${ }^{2}$, Ferhan Cantürk ${ }^{1}$ \\ IOndokuz Mayıs Üniversitesi Tıp Fakültesi, Fiziksel Tıp ve Rehabilitasyon Anabilim Dalı, Samsun, Turkey \\ ²Ondokuz Mayıs Üniversitesi Tıp Fakültesi, Biyoistatistik Anabilim Dalı, Samsun, Turkey
}

\begin{abstract}
Objective: An increase in the prevalence of physical and mental disorders, such as depression with aging, together with environmental factors, may cause deterioration in the quality of life. The present study was conducted to investigate the effects of the general state of health and personal characteristics on quality of life in elderly patients, and to evaluate the relationship between the level of depressive symptoms, pain intensity, and quality of life.
\end{abstract}

Materials and Methods: One hundred twenty individuals $\geq 65$ years of age were included in the study. All subjects were evaluated using a questionnaire form, including items about demographic and clinical information (doctor diagnosed of chronic diseases, such as diabetes mellitus, hypertension, cardiovascular diseases, and hyperlipidemia). The intensity of pain was assessed by a visual analogue scale (VAS), quality of life was assessed by the Short Form-36 (SF-36), and the level of depressive symptoms was assessed by the Geriatric Depression Scale (GDS).

Results: The mean age of the subjects was $71.53 \pm 4.69$ years; $88.3 \%(n=106)$ were females and $11.7 \%(n=14)$ were males. Chronic diseases were present in $80.8 \%$ of the subjects $(n=97)$ and hypertension was the most prevalent disease (49.7\%). There was a significant negative correlation between quality of life and pain intensity and level of depression. When evaluated according to educational status, significant differences were found between the groups in some quality of life parameters (physical functioning, social functioning, mental health, and bodily pain) and the GDS $(p<0.05)$. When evaluated according to the presence of chronic diseases, significant differences were also found between the groups in physical functioning, social functioning, vitality, and bodily pain subscales of quality of life measures and the GDS $(p<0.05)$.

Conclusion: The presence of a chronic disease and low educational status reduce the quality of life and increase the level of depression in the elderly. Quality of life is negatively affected with the level of depression and the pain intensity. Efforts to improve these conditions may contribute to improving the quality of life of elderly individuals.

(Turk J Rheumatol 2010; 25: 165-73)

Key words: Elderliness, quality of life, depression, pain, chronic disease

Received: 02.01.2009 Accepted: 05.03.2009

\section{Özet}

Amaç: Yașlanma ile depresyon gibi ruhsal ve bedensel hastalıkların sıklığındaki artıș, çevresel faktörlerin katkısıyla yașam kalitesinin bozulmasına neden olabilir. Bu çalıșma, yașlı hastaların genel sağlık durumlarının ve kișisel özeliklerinin yașam kalitelerine etkisini belirlemek, depresif belirti düzeyleri, ağrı șiddeti ve yașam kalitesi ilișkisini araștırmak amacıyla yapıldı.

Yöntem ve Gereçler: Çalıșmaya 65 yaș ve üzeri 120 kiși alındı. Demografik özellikleri ve hekim tanılı kronik hastalıklarının varlığını (diyabetes mellitus, hipertansiyon, kardiovasküler hastalık, hiperlipidemi) sorgulayan bilgi anketi, ağrı șiddeti için Görsel Analog Skala (GAS), yașam kalitesi ölçümü için Kısa form 36 (SF-36), depresyon düzeyi için GDÖ (Geriatrik Depresyon Ölçeği) uygulandı.

Bulgular: Katılımcıların yas ortalaması $71.53 \pm 4.69$ olup, $\% 88.3$ 'ü $(n=106)$ kadın, \%11.7'si $(n=14)$ erkek idi. Hastaların \%80.8'inde $(n=97)$ kronik hastalık var olup, hipertansiyon (\%49.7) ilk sırada yeralmaktaydı. Yașam kalitesi ile ağrı ve depresyon düzeyleri arasında anlamlı negatif korelasyon vardı. Eğitim durumlarına göre değerlendirildiğinde, gruplar arasında yașam kalitesi bazı parametrelerinde (fiziksel fonksiyon, sosyal fonksiyon, mental sağlık, ağrı) ve GDÖ'de anlamlı fark saptandı $(p<0.05)$. Kronik hastalık varlığına göre değerlendirildiğinde ise, gruplar arasında yașam kalitesinin fiziksel fonksiyon, sosyal fonksiyon, zindelik ve ağrı parametresinde ve GDÖ'de anlamlı fark bulundu $(p<0.05)$.

Sonuç: Yaşıılarda kronik hastalık varlığı ve eğitim düzeyi düșüklüğü yașam kalitesini azaltmakta, depresyon düzeyini artırmaktadır. Depresyon düzeyi ve ağrı șiddeti ile yașam kalitesi olumsuz etkilenmektedir. Belirlenen koșulların iyileștirilmesine yönelik çalıșmalar yașam kalitesi artmıs yașlı populasyon olușturulmasına katkı sağlayabilir.

(Turk J Rheumatol 2010; 25: 165-73)

Anahtar sözcükler: Yașlılık, yașam kalitesi, depresyon, ağrı, kronik hastalık

Alındığı Tarih: 02.01.2009 Kabul Tarihi: 05.03.2009

Address for Correspondence: Dr. Dilek Durmuş, Ondokuz Mayıs Üniversitesi Tıp Fakültesi, Fiziksel Tıp ve Rehabilitasyon Anabilim Dalı, Samsun, Turkey Phone: +903623121919 E-mail: drdilekdurmus@yahoo.com doi: $10.5152 /$ tjr. 2010.23 


\section{Introduction}

Individuals over 65 years of age are currently classified as elderly. Aging is an inevitable process of every living organism and is associated with a decrease in the homeostatic control and reserve capacity of the organ systems, the ability to adapt to environmental factors, and the capacity of a stress response (1). Dramatic changes in birth and death rates in the 20th century increase will reach 24 million in $2030(2,3)$. The proportion of elderly in the entire population of Turkey in 2003 was $9.8 \%$. Owing to the reduction in reproductive rate in the last two decades and the increased capability in the early diagnosis and treatment of chronic diseases resulting in an increase in survival, it has been estimated that this proportion will rise by $2-3$-fold within 30 years $(4,5)$.

Besides being an inevitable physiologic process, aging is one of the major causes of reduction in the quality of life due to its chronologic, biological, social, and psychological dimensions. A higher prevalence of chronic diseases and disabilities in the elderly compared to other age groups, and accordingly limitations in their social activities, lead to a reduction in the quality of life. Quality of life can be defined as an individual's perception of happiness and satisfaction with life, and position in life in the context of the culture and value systems in which they live and in relation to their expectations, values and concerns in corporating with physical health $(6,7)$. Studies on health-related quality of life have evaluated the basic framework of quality of life and reported that it is composed of several dimensions, including physical function, social and psychological factors, life satisfaction, well-being, and awareness of health status (8). Physical function dimension includes activities of daily living and effects of chronic diseases (if present) and their treatment modalities on physical functions. The social function dimension includes one's relationships with family members, friends, and society. The psychological function dimension includes emotional states, such as depression, anxiety, fear, anger, and happiness $(9,10)$.

Depression is one of the common psychiatric disorders affecting the elderly population (11). In studies conducted in various countries, the prevalence of depression in the elderly has been reported to be $15 \%(12,13)$. The prevalence of depressive disorders in the elderly has been reported to be $13.5 \%-41.5 \%$ in Turkey $(14,15)$. Risk factors for depression in the elderly are not so different from those in the young population; however, exposure to these risk factors varies by age. Female gender, problems related to physical health, neurotic personality traits, a history of depression, living in nursing homes, inadequate life events, and lack of social support are significant risk factors for the development of depression in the elderly (16).

Health maintenance and improvement in the quality of life in the elderly population can be possible by implementation of recommendations based on scientific research. The aim of the present study was to investigate the effects of general health status, personal characteristics and habits, as well as physical and social environment on quality of life in elderly patients, and to evaluate the relationship between the level of depressive symptoms, pain intensity, and quality of life.

\section{Materials and Methods}

The present study was conducted in 120 individuals $\geq 65$ years of age admitted to Ondokuz Mayis University, Faculty of Medicine, Department of Physical Medicine and Rehabilitation between April 1 and November 30, 2008. All patients were informed about the objectives and contents of the study, and verbal informed consents were obtained.

All subjects were evaluated by a face-to-face interview technique using a questionnaire form including demographic and clinical information (age, height, weight, gender, marital status, educational status, occupational status, number of children, source of income, presence of chronic diseases, smoking status, sleeping problems, perceptions of aging with questions, such as 'What do you think about aging?' and 'Do you feel old?', and clinical diagnosis). Following the questionnaire, a quality of life measure, a depression scale, and a visual analogue scale (VAS) for pain intensity were performed.

\section{Scales used in the study}

Short Form-36 (SF-36): This scale has been used in many different languages and cultures to measure quality of life (17). The validity and reliability of the Turkish version of SF-36 has been reported by Kocyigit et al. (18). It is composed of simple questions on 8 subscales, including physical functioning, social functioning, physical role limitation, emotional role limitation, bodily pain, mental health, vitality, and general health. High scores on all subscales of SF-36 reflect better quality of life, and reduction in scores indicates deterioration in quality of life. The scale was completed by patients under the supervision of a physician in order to obtain more accurate results.

Geriatric Depression Scale (GDS): This screening instrument includes 30 items evaluating the level of depressive symptoms within the last week. It is a selfestimated scale and the items are responded to yes or no. It has been developed by Yesa-vage et al. (19) and the validity and reliability of the Turkish version has been reported $(20,21)$. High scores indicate a high level of depressive symptoms. In the Turkish version of the scale, no cut-off value to define the risk for depression has been reported. Therefore, GDS scores were not compared with other variables in our study. 
Pain Visual Analogue Scale (VAS): The patients were asked to mark their intensity of pain on a $10 \mathrm{~cm}$ horizontal line with "no pain" on one end and "unbearable pain" on the other end.

\section{Statistical analysis}

SPSS 13.0 for Windows was used for statistical analyses. A normal distribution of variables was tested by the Kolmogorov-Smirnov test. Results of descriptive statistics were expressed as the arithmetic mean \pm standard deviation for parametric variables and as the median and range (maximum-minimum) for non-parametric variables. Student's t-test was used for comparison of variables according to gender since all variables were normally distributed. The Mann Whitney-U test was used for the comparison of variables according to the presence of chronic disease because not all variables were normally distributed.

When the study population was grouped according to age and educational status, non-normally distributed variables (SF-36 role physical and role emotional subscales, and pain VAS) were analyzed by Kruskal-Wallis analysis, and normally distributed variables were analyzed by oneway analysis of variance. When a statistically significant difference was noted, Tukey's multiple comparison test was performed in order to demonstrate the difference between the groups. Spearman correlation analysis was performed to evaluate the relationship between quality of life subscales, depression, and pain intensity because not all variables were normally distributed. The level of $\mathrm{p}<0.05$ was accepted as statistically significant.

\section{Results}

The mean age of the study population $(n=120)$ was $71.53 \pm 4.69$ years (range, $65-87$ years); $88.3 \%$ were females $(n=106)$ and $11.7 \%(n=14)$ were males. Among the study population, $40.8 \%(n=49)$ were illiterate, $15 \% \quad(n=18)$ were literate, $37.5 \% \quad(n=45)$ had a primary school education, and $6.7 \%(n=8)$ had a secondary school or higher education. Of the study population, $57.5 \% \quad(n=69)$ were married and $42.5 \% \quad(n=51)$ were widowed. As shown in Table 1, 72.0\% $(n=86)$ were housewives, $23.0 \%$ $(n=28)$ were retired, $3.0 \%(n=4)$ were farmers, and $2 \%$ $(n=2)$ were self-employed.

While $19.2 \%$ of the elderlies $(n=23)$ did not have any chronic disease, $80.8 \%(n=97)$ had at least 1 chronic disease. Hypertension $(49.7 \%, n=84)$ was the most frequent chronic disease, followed by hyperlipidemia (18.9\%, $n=32)$, diabetes mellitus $(16.0 \%, n=27)$, and cardiovascular diseases $(15.4 \%, \mathrm{n}=26)$. Of the study population, $88.3 \% \quad(n=106)$ were diagnosed with osteoarthritis, $11.7 \% \quad(n=14)$ were diagnosed with inflammatory disease, and $42.5 \%(n=51)$ were diagnosed with osteoporosis (Table 2). The distribution of patients concerning their habits and perception of aging are also presented in Table 2 .

A significant negative correlation was found between quality of life and pain intensity and level of depression $(p<0.05$; Table 3).

When the participants were divided into 4 age groups and evaluated, the GDS score in patients $>80$ years of age was higher compared to other age groups $(p<0.05)$. No difference was noted between age groups in terms of quality of life and pain VAS scores ( $p>0.05$; Table 4 ). No significant gender-related differences were noted in quality of life, pain VAS, and GDS scores ( $p>0.05$; Table 5).

Table 1. Demographic features of the study population

\begin{tabular}{|c|c|c|}
\hline Features & Mean & Standard Deviation \\
\hline Age (years) & 71.53 & 4.69 \\
\hline Height $(\mathrm{cm})$ & 159.21 & 7.34 \\
\hline Weight (kg) & 73.87 & 14.70 \\
\hline \multirow[t]{2}{*}{ BMI $\left(\mathrm{kg} / \mathrm{m}^{2}\right)$} & 29.14 & 5.58 \\
\hline & $\mathbf{N}$ & $(\%)$ \\
\hline \multicolumn{3}{|l|}{ Gender } \\
\hline Female & 106 & $(88.3)$ \\
\hline Male & 14 & $(11.7)$ \\
\hline \multicolumn{3}{|l|}{ Marital status } \\
\hline Married & 69 & $(57.5)$ \\
\hline Widowed & 51 & $(42.5)$ \\
\hline \multicolumn{3}{|l|}{ Educational status } \\
\hline Illiterate & 49 & $(40.8)$ \\
\hline Literate & 18 & $(15.0)$ \\
\hline Primary school & 45 & $(37.5)$ \\
\hline Secondary school and higher & 8 & $(6.7)$ \\
\hline \multicolumn{3}{|l|}{ Occupational status } \\
\hline Housewife & 86 & $(72.0)$ \\
\hline Retired & 28 & $(23.0)$ \\
\hline Farmer & 4 & $(3.0)$ \\
\hline Self-employed & 2 & $(2.0)$ \\
\hline \multicolumn{3}{|l|}{ Number of children } \\
\hline None & 6 & $(5.0)$ \\
\hline 1 & 3 & $(2.5)$ \\
\hline 2 & 18 & $(15.0)$ \\
\hline 3 & 27 & $(22.5)$ \\
\hline 4 & 24 & $(20.0)$ \\
\hline 5 & 24 & $(20.0)$ \\
\hline $6+$ & 18 & $(15)$ \\
\hline \multicolumn{3}{|l|}{ Income level } \\
\hline None & 36 & $(30.0)$ \\
\hline Retirement pension & 75 & $(62.6)$ \\
\hline Government support & 5 & $(4.0)$ \\
\hline Real estate income & 2 & (1.7) \\
\hline Family support & 2 & (1.7) \\
\hline
\end{tabular}


Table 2. The distribution of patients according to their clinical features, habits and perception of aging

\begin{tabular}{lc}
\hline Features & N (\%) \\
\hline Presence of chronic disease & $97(80.8)$ \\
Yes & $23(19.2)$ \\
No & \\
Chronic diseases & $84(49.7)$ \\
Hypertension & $32(18.9)$ \\
Hyperlipidemia & $27(16.0)$ \\
Diabetes Mellitus & $26(15.4)$ \\
Cardiovascular system disease & \\
Smoking status & $102(85.0)$ \\
Never smoked & $8(6.7)$ \\
Quit smoking & $10(8.3)$ \\
Current smoker & \\
Musculoskeletal conditions & $106(88.3)$ \\
Osteoarthritis & $14(11.7)$ \\
Inflammatory disease & \\
Osteoporosis & $51(42.5)$ \\
Present & $69(57.5)$ \\
Absent & \\
Sleeping problems & \\
None & $41(34.2)$ \\
Rare & $57(47.5)$ \\
Often (more than once a week) & $22(18.3)$ \\
What do you think about aging? & \\
It is good & $16(13.3)$ \\
It is bad & $58(48.3)$ \\
Do you feel old? & $46(38.4)$ \\
Yes & \\
No & \\
Unable to decide & $(264.2)$ \\
\hline
\end{tabular}

Table 3. The correlation between quality of life and pain intensity and level of depression

\begin{tabular}{lccccc}
\hline & \multicolumn{2}{c}{ GDS } & \multicolumn{2}{c}{ Pain VAS } \\
& $\mathbf{r}$ & $\mathbf{p}$ & $\mathbf{r}$ & $\mathbf{p}$ \\
\hline SF-36 subscales & & & & \\
$\quad$ Physical functioning & $-0.436(* *)$ & 0.001 & $-0.375(* *)$ & 0.001 \\
Social functioning & $-0.635(* *)$ & 0.001 & $-0.431(* *)$ & 0.001 \\
Role physical & $-0.197(*)$ & 0.031 & $-0.441(* *)$ & 0.001 \\
Role emotional & $-0.434(* *)$ & 0.001 & $-0.273(* *)$ & 0.003 \\
Mental health & $-0.664(* *)$ & 0.001 & $-0.194(*)$ & 0.034 \\
Vitality & $-0.730(* *)$ & 0.001 & $-0.393(* *)$ & 0.001 \\
Bodily pain & $-0.385(* *)$ & 0.001 & $-0.854(* *)$ & 0.001 \\
General health & $-0.703(* *)$ & 0.001 & $-0.274(* *)$ & 0.002 \\
Pain VAS & $0.280(* *)$ & 0.002 & & \\
\hline GDS: Geriatric depression scale, VAS: Visual analogue scale, SF-36: Short \\
form-36
\end{tabular}

When participants were evaluated according to level of education, a significant difference was noted in some of the quality of life subscales (physical functioning, social functioning, mental health, and bodily pain) and GDS ( $p<0.05$; Table 6). A significant difference was noted between patients according to presence of chronic disease in physical functioning, social functioning, vitality, and bodily pain subscales of quality of life and GDS $(p<0.05$; Table 7$)$.

\section{Discussion}

The present study was conducted in order to determine the effects of the general state of health and personal characteristics of elderly patients on quality of life, and to evaluate the relationship between the level of depressive symptoms, pain intensity, and quality of life.

Most of the subjects in the study population were females. Although this might be an incidental finding, it might also be due to the longer lifespan, higher prevalence of symptoms and diseases, and also higher admission rates to health care services in females. In a Spanish cross-sectional study conducted in 3030 individuals $>60$ years of age, it was reported that females had a higher rate of admission to health care services compared to males (22).

Turgul et al. (23) reported that in individuals $>65$ years of age, the mean quality of life scores of males was higher than females. Cingil and Bodur (24) reported similar results in another study conducted in elderly population. In contrast, Luleci et al. (25) did not note a significant difference in the mean quality of life scores of males and females. Similarly, in the present study no significant gender-related differences were found in quality of life scores.

Age-related changes in the organism may have an effect on the quality of life. Skevington et al. (26) reported that increasing age had a negative effect on all aspects of the quality of life. Similarly, Arslantas et al. (27) also noted a reduction in the mean quality of life scores (except social life) by increasing age. In contrast to these findings, we did not find a significant difference between quality of life scores of different age groups; however, we observed an increase in the levels of depression by increasing age. This suggests that a reduction in the quality of life in the elderly population might be associated with additional factors rather than aging itself.

Most of the participants were illiterate $(40.8 \%)$, and the proportion of those with secondary school or higher education was only $6.7 \%$. Arslantas et al. (27) reported that the mean quality of life scores were lower in individuals with a lower level of education. Similarly, quality of life has been reported to be reduced in elderly individuals with a lower level of education in Taiwan (28). When the study population were evaluated according to 
Table 4. Assessment of pain intensity and quality of life according to age groups

\begin{tabular}{|c|c|c|c|c|}
\hline & Age groups & Mean \pm SD & Median (range) & $\mathbf{p}$ \\
\hline \multicolumn{5}{|l|}{ SF-36 subscales } \\
\hline \multirow{4}{*}{ Physical functioning } & $65-69$ & $37.90 \pm 25.97$ & $40.0(0-95)$ & \multirow{4}{*}{0.155} \\
\hline & $70-74$ & $47.43 \pm 21.84$ & $50.0(0-95)$ & \\
\hline & $75-79$ & $37.50 \pm 24.58$ & $30.0(0-100)$ & \\
\hline & $80+$ & $29.29 \pm 20.29$ & $25.0(10-70)$ & \\
\hline \multirow{4}{*}{ Social functioning } & $65-69$ & $49.94 \pm 21.79$ & $49.5(11-88)$ & \multirow{4}{*}{0.119} \\
\hline & $70-74$ & $47.46 \pm 16.17$ & $44.0(11-88)$ & \\
\hline & $75-79$ & $52.46 \pm 17.54$ & $44.0(22-88)$ & \\
\hline & $80+$ & $33.00 \pm 22.89$ & $44.0(0-66)$ & \\
\hline \multirow{4}{*}{ Physical role } & $65-69$ & $14.50 \pm 31.57$ & $0.0(0-100)$ & \multirow{4}{*}{0.191} \\
\hline & $70-74$ & $27.14 \pm 38.04$ & $0.0(0-100)$ & \\
\hline & $75-79$ & $21.43 \pm 37.70$ & $0.0(0-100)$ & \\
\hline & $80+$ & $25.00 \pm 38.18$ & $0.0(0-100)$ & \\
\hline \multirow{4}{*}{ Emotional role } & $65-69$ & $36.54 \pm 42.13$ & $16.5(0-100)$ & \multirow{4}{*}{0.954} \\
\hline & $70-74$ & $39.83 \pm 40.99$ & $33.0(0-100)$ & \\
\hline & $75-79$ & $41.54 \pm 44.04$ & $33.0(0-100)$ & \\
\hline & $80+$ & $37.86 \pm 35.56$ & $33.0(0-100)$ & \\
\hline \multirow{4}{*}{ Mental health } & $65-69$ & $56.88 \pm 15.42$ & $60.0(28-92)$ & \multirow{4}{*}{0.100} \\
\hline & $70-74$ & $58.06 \pm 15.40$ & $60.0(28-84)$ & \\
\hline & $75-79$ & $63.71 \pm 13.06$ & $64.0(36-88)$ & \\
\hline & $80+$ & $49.71 \pm 17.10$ & $52.0(24-72)$ & \\
\hline \multirow{4}{*}{ Vitality } & $65-69$ & $48.50 \pm 19.60$ & $47.5(15-85)$ & \multirow{4}{*}{0.354} \\
\hline & $70-74$ & $52.71 \pm 18.32$ & $50.0(10-85)$ & \\
\hline & $75-79$ & $53.39 \pm 15.57$ & $55.0(25-85)$ & \\
\hline & $80+$ & $42.14 \pm 16.54$ & $50.0(10-55)$ & \\
\hline \multirow{4}{*}{ Bodily pain } & $65-69$ & $39.18 \pm 24.81$ & $44.0(0-100)$ & \multirow{4}{*}{0.752} \\
\hline & $70-74$ & $43.69 \pm 14.97$ & $44.0(0-100)$ & \\
\hline & $75-79$ & $42.82 \pm 16.49$ & $44.0(11-88)$ & \\
\hline & $80+$ & $39.29 \pm 27.57$ & $44.0(0-77)$ & \\
\hline \multirow{4}{*}{ General health } & $65-69$ & $42.30 \pm 19.02$ & $40.0(0-80)$ & \multirow{4}{*}{0.548} \\
\hline & $70-74$ & $46.29 \pm 18.60$ & $40.0(10-80)$ & \\
\hline & $75-79$ & $44.82 \pm 17.87$ & $45.0(0-55)$ & \\
\hline & $80+$ & $36.43 \pm 17.96$ & $40.0(0-50)$ & \\
\hline \multirow{4}{*}{ Pain VAS } & $65-69$ & $6.84 \pm 2.66$ & $6.0(2-10)$ & \multirow{4}{*}{0.174} \\
\hline & $70-74$ & $5.94 \pm 1.76$ & $6.0(2-10)$ & \\
\hline & $75-79$ & $6.89 \pm 2.31$ & $6.0(2-9)$ & \\
\hline & $80+$ & $5.86 \pm 3.07$ & $6.0(2-10)$ & \\
\hline \multirow{4}{*}{ GDS } & $65-69$ & $13.82 \pm 8.07^{a}$ & $13.5(1-29)^{a}$ & \multirow{4}{*}{0.028 * } \\
\hline & $70-74$ & $12.74 \pm 6.57^{a}$ & $12.0(1-28)^{a}$ & \\
\hline & $75-79$ & $11.79 \pm 7.06^{a}$ & $9.5(2-27)^{a}$ & \\
\hline & $80+$ & $21.43 \pm 11.14^{b *}$ & $17.0(7-40)^{b}$ & \\
\hline
\end{tabular}

SD: Standard deviation, SF-36: Short form-36, VAS: Visual analogue scale, GDS: Geriatric depression scale, a, b, ab: same letters denote that there is no significant difference between the groups 


\begin{tabular}{|c|c|c|c|c|}
\hline & Gender & Mean \pm SD & Median (range) & $\mathbf{p}$ \\
\hline \multicolumn{5}{|l|}{ SF-36 Subscales } \\
\hline Physical functioning & $\begin{array}{l}\text { Female } \\
\text { Male }\end{array}$ & $\begin{array}{l}39.20 \pm 23.21 \\
46.79 \pm 32.67\end{array}$ & $\begin{array}{c}38.7(0-100) \\
37.5(0-95)\end{array}$ & 0.277 \\
\hline Social functioning & $\begin{array}{c}\text { Female } \\
\text { Male }\end{array}$ & $\begin{array}{l}47.58 \pm 19.59 \\
58.14 \pm 18.01\end{array}$ & $\begin{array}{c}44.0(0-88) \\
55.0(33-88)\end{array}$ & 0.058 \\
\hline Physical role & $\begin{array}{l}\text { Female } \\
\text { Male }\end{array}$ & $\begin{array}{l}18.40 \pm 33.50 \\
35.71 \pm 45.69\end{array}$ & $\begin{array}{l}0.0(0-100) \\
0.0(0-100)\end{array}$ & 0.085 \\
\hline Emotional role & $\begin{array}{l}\text { Female } \\
\text { Male }\end{array}$ & $\begin{array}{l}37.90 \pm 40.68 \\
45.14 \pm 48.18\end{array}$ & $\begin{array}{l}33.0(0-100) \\
33.0(0-100)\end{array}$ & 0.541 \\
\hline Mental health & $\begin{array}{l}\text { Female } \\
\text { Male }\end{array}$ & $\begin{array}{l}57.62 \pm 15.51 \\
64.29 \pm 11.47\end{array}$ & $\begin{array}{l}60.0(24-92) \\
64.0(44-80)\end{array}$ & 0.124 \\
\hline Vitality & $\begin{array}{l}\text { Female } \\
\text { Male }\end{array}$ & $\begin{array}{l}49.39 \pm 18.01 \\
58.93 \pm 18.62\end{array}$ & $\begin{array}{l}50.0(10-85) \\
60.0(25-85)\end{array}$ & 0.066 \\
\hline Bodily pain & $\begin{array}{l}\text { Female } \\
\text { Male }\end{array}$ & $\begin{array}{l}40.17 \pm 20.34 \\
50.29 \pm 20.56\end{array}$ & $\begin{array}{l}44.0(0-100) \\
49.5(22-88)\end{array}$ & 0.083 \\
\hline General health & $\begin{array}{l}\text { Female } \\
\text { Male }\end{array}$ & $\begin{array}{l}42.83 \pm 18.40 \\
50.36 \pm 18.96\end{array}$ & $\begin{array}{c}40.0(0-85) \\
52.5(20-80)\end{array}$ & 0.154 \\
\hline Pain VAS & $\begin{array}{l}\text { Female } \\
\text { Male }\end{array}$ & $\begin{array}{l}6.63 \pm 2.34 \\
5.99 \pm 2.66\end{array}$ & $\begin{array}{l}6.0(2-10) \\
6.0(2-9)\end{array}$ & 0.214 \\
\hline GDS & $\begin{array}{c}\text { Female } \\
\text { Male }\end{array}$ & $\begin{array}{c}13.98 \pm 7.81 \\
9.64 \pm 7.17\end{array}$ & $\begin{array}{l}13.5(2-40) \\
7.5(1-26)\end{array}$ & 0.051 \\
\hline
\end{tabular}

level of education, it was found that the quality of life scores (mental health, bodily pain, physical and social functioning subscales) reduced and the level of depression increased in lower education level.

Canbaz et al. (29) reported that the most frequent chronic diseases in the elderly were hypertension and cardiovascular system disease. Arslan et al. (30) reported that hypertension was the most frequent chronic disease, following osteoarthritis, heart failure, and diabetes mellitus. Orfila et al. (31) reported in their cross-sectional study, including 544 participants, that the higher prevalence of disease and chronic conditions (mellitus, depression, arthritis, and reduced functional capacity) was the main reason for a reduction in the quality of life in the elderly. The relationship between quality of life and chronic conditions was investigated in a multi-center study conducted in eight different countries, and chronic conditions (allergy, arthritis, chronic heart failure, chronic pulmonary disease, hypertension, diabetes mellitus, and ischemic heart disease) affecting quality of life were similar, despite variation in prevalence between countries (32). Chronic diseases were present in $80.8 \%$ of the present study population. Hypertension was the most frequent chronic disease, followed by hyperlipidemia, diabetes mellitus, and cardiovascular system diseases. Quality of life was lower and the level of depression was higher in elderly patients with systemic chronic diseases compared to those without.
It has been suggested that problems affecting the health status of the elderly should be determined and solved in order to improve quality of life (29). Insomnia is among the most common health problems in the elderly (2). Smoking is a significant risk factor for major causes of morbidity and mortality in the elderly, including heart disease, stroke, chronic pulmonary disease, and lung cancer (33). In the present study, smoking status and sleeping problems were also questioned; accordingly, of the individuals $8.3 \%$ were smoking, whereas $47.5 \%$ and $18.3 \%$ were reported that they had sleeping problems åoccasionally and more than once a week, respectively. Moreover, $48.3 \%$ of individuals generally considered aging as an awful period.

It has been reported that depression is a frequent problem and might have a significant effect on the quality of life in the elderly population (30). Ilhan et al. (34) found that depression was present in $48.2 \%$ of 191 elderly individuals living in a nursing home. In another study, depression was reported in $29 \%$ of the elderly subjects living in their homes, and $41 \%$ of those living in nursing homes (35). Since a cut-off value for depression was not established in the present study, a prevalence rate for depression could not be provided, thus quality of life of individuals with depression could not be evaluated. However, it was noted that quality of life were reduced as depression scores and pain intensity scores were increased in the present study population. 
Table 6. Comparison of quality of life, pain intensity, and level of depression according to educational status

\begin{tabular}{|c|c|c|c|c|}
\hline & Educational status & Mean \pm SD & Median (range) & $\mathbf{p}$ \\
\hline \multicolumn{5}{|l|}{ SF-36 Subscales } \\
\hline \multirow[t]{4}{*}{ Physical functioning } & Illiterate & $32.86 \pm 23.47^{a}$ & $30.0(0-100)^{a}$ & 0.02 \\
\hline & Literate & $46.39 \pm 25.82^{\mathrm{ab}}$ & $47.5(0-80)^{a b}$ & \\
\hline & Primary school & $42.67 \pm 23.34^{a b}$ & $45.0(0-95)^{a b}$ & \\
\hline & Secondary school and higher & $55.63 \pm 23.67 \mathrm{~b}$ & $52.5(20-95)^{b}$ & \\
\hline \multirow[t]{4}{*}{ Social functioning } & Illiterate & $44.00 \pm 20.20^{a}$ & $44.0(0-88)^{a}$ & 0.04 \\
\hline & Literate & $52.28 \pm 18.69 a b$ & $52.5(22-88)^{a b}$ & \\
\hline & Primary school & $50.11 \pm 18.84^{a b}$ & $44.0(11-88)^{a b}$ & \\
\hline & Secondary school and higher & $63.25 \pm 15.27^{b}$ & $66.0(33-77)^{b}$ & \\
\hline \multirow[t]{4}{*}{ Physical role } & Illiterate & $17.86 \pm 33.46^{a}$ & $0(0-100)^{a}$ & 0.168 \\
\hline & Literate & $30.56 \pm 42.49^{a}$ & $0(0-100)^{a}$ & \\
\hline & Primary school & $16.11 \pm 33.35^{a}$ & $0(0-100)^{a}$ & \\
\hline & Secondary school and higher & $37.50 \pm 37.79 a$ & $37.5(0-100)^{a}$ & \\
\hline \multirow[t]{4}{*}{ Emotional role } & Illiterate & $39.31 \pm 41.16^{a}$ & $33.0(0-100)^{a}$ & 0.995 \\
\hline & Literate & $38.67 \pm 39.88^{a}$ & $33.0(0-100)^{a}$ & \\
\hline & Primary school & $38.40 \pm 43.15^{a}$ & $33.0(0-100)^{a}$ & \\
\hline & Secondary school and higher & $37.38 \pm 45.15^{a}$ & $16.5(0-100)^{a}$ & \\
\hline \multirow[t]{4}{*}{ Mental health } & Illiterate & $54.12 \pm 14.72^{a}$ & $56.0(24-84)^{a}$ & 0.003 \\
\hline & Literate & $60.22 \pm 12.53^{a}$ & $60.0(40-88)^{a}$ & \\
\hline & Primary school & $59.47 \pm 15.27^{a}$ & $60.0(28-92)^{a}$ & \\
\hline & Secondary school and higher & $74.50 \pm 12.63^{b}$ & $78.0(52-92)^{b}$ & \\
\hline \multirow[t]{4}{*}{ Vitality } & Illiterate & $45.20 \pm 16.45^{a}$ & $45.0(10-85)^{a}$ & 0.055 \\
\hline & Literate & $53.89 \pm 14.60^{a}$ & $52.5(15-85)^{a}$ & \\
\hline & Primary school & $53.44 \pm 20.61^{a}$ & $50.0(15-85)^{a}$ & \\
\hline & Secondary school and higher & $58.75 \pm 16.42^{a}$ & $60.0(25-80)^{a}$ & \\
\hline \multirow[t]{4}{*}{ Bodily pain } & Illiterate & $35.02 \pm 20.6^{a}$ & $33.0(0-77)^{a}$ & 0.02 \\
\hline & Literate & 48. $89 \pm 16.54^{\mathrm{ab}}$ & $49.5(22-88)^{a b}$ & \\
\hline & Primary school & $43.53 \pm 20.90^{a b}$ & $44.0(0-100)^{a b}$ & \\
\hline & Secondary school and higher & $50.88 \pm 16.56^{b}$ & $55.0(33-77)^{b}$ & \\
\hline \multirow[t]{4}{*}{ General health } & Illiterate & $40.61 \pm 20.45^{a}$ & $40.0(0-85)^{a}$ & 0.133 \\
\hline & Literate & $43.33 \pm 14.45^{a}$ & $42.5(25-75)^{a}$ & \\
\hline & Primary school & $44.89 \pm 17.53^{a}$ & $45.0(0-80)^{a}$ & \\
\hline & Secondary school and higher & $56.88 \pm 16.24^{a}$ & $65.0(20-70)^{a}$ & \\
\hline \multirow[t]{4}{*}{ Pain VAS } & Illiterate & $7.06 \pm 2.55^{a}$ & $6.0(2-10)^{a}$ & 0.178 \\
\hline & Literate & $6.11 \pm 1.93^{a}$ & $6.0(2-9)^{a}$ & \\
\hline & Primary school & $6.18 \pm 2.35^{a}$ & $6.0(2-10)^{a}$ & \\
\hline & Secondary school and higher & $6.25 \pm 2.18^{a}$ & $6.0(2-10)^{a}$ & \\
\hline \multirow[t]{4}{*}{ GDS } & Illiterate & $15.80 \pm 7.28^{a}$ & $15.0(2-29)^{a}$ & 0.02 \\
\hline & Literate & $11.67 \pm 7.02^{a b}$ & $11.5(2-29)^{a b}$ & \\
\hline & Primary school & $12.64 \pm 8.07 \mathrm{ab}$ & $11.0(1-40)^{a b}$ & \\
\hline & Secondary school and higher & $8.00 \pm 8.07^{b}$ & $5.0(1-26)^{b}$ & \\
\hline
\end{tabular}

SD: Standard deviation, SF-36: Short form-36, VAS: Visual analogue scale, GDS: Geriatric depression scale, a, b, ab: same letters denote that there is no significant difference between the groups, $p$ value is significant when $<0.05$ 
Table 7. Comparison of quality of life, pain intensity, and level of depression in subjects according to presence of chronic disease

\begin{tabular}{|c|c|c|c|c|}
\hline & Chronic disease & Mean \pm SD & Median (range) & $p$ \\
\hline \multicolumn{5}{|l|}{ SF-36 Subscales } \\
\hline \multirow[t]{2}{*}{ Physical functioning } & Yes & $37.89 \pm 24.50$ & $40(0-100)$ & \multirow{2}{*}{0.030} \\
\hline & No & $49.35 \pm 22.47$ & $50(0-95)$ & \\
\hline \multirow[t]{2}{*}{ Social functioning } & Yes & $45.99 \pm 19.44$ & $44(0-88)$ & \multirow{2}{*}{0.001} \\
\hline & No & $60.74 \pm 15.86$ & $55(44-88)$ & \\
\hline \multirow[t]{2}{*}{ Physical role } & Yes & $17.78 \pm 33.26$ & $0(0-100)$ & \multirow{2}{*}{0.128} \\
\hline & No & $31.52 \pm 42.11$ & $0(0-100)$ & \\
\hline \multirow[t]{2}{*}{ Emotional role } & Yes & $36.62 \pm 40.61$ & $33(0-100)$ & \multirow{2}{*}{0.279} \\
\hline & No & $47.70 \pm 44.72$ & $33(0-100)$ & \\
\hline \multirow[t]{2}{*}{ Mental health } & Yes & $57.57 \pm 15.55$ & $60(24-92)$ & \multirow{2}{*}{0.205} \\
\hline & No & $61.91 \pm 13.42$ & $64(40-92)$ & \\
\hline \multirow[t]{2}{*}{ Vitality } & Yes & $48.61 \pm 18.71$ & $50(10-85)$ & \multirow{2}{*}{0.028} \\
\hline & No & $58.48 \pm 13.93$ & $55(40-85)$ & \\
\hline \multirow[t]{2}{*}{ Bodily pain } & Yes & $39.36 \pm 21.61$ & $44(0-100)$ & \multirow{2}{*}{0.019} \\
\hline & No & $49.74 \pm 12.35$ & $55(22-66)$ & \\
\hline \multirow[t]{2}{*}{ General health } & Yes & $42.78 \pm 19.36$ & $40(0-85)$ & \multirow{2}{*}{0.058} \\
\hline & No & $47.78 \pm 19.36$ & $45(25-80)$ & \\
\hline \multirow[t]{2}{*}{ Pain VAS } & Yes & $6.69 \pm 2.48$ & $6(2-10)$ & \multirow{2}{*}{0.087} \\
\hline & No & $5.87 \pm 1.84$ & $6(3-9)$ & \\
\hline \multirow[t]{2}{*}{ GDS } & Yes & $14.39 \pm 8.14$ & $15(1-40)$ & \multirow{2}{*}{0.009} \\
\hline & No & $9.61 \pm 4.85$ & $10(1-21)$ & \\
\hline
\end{tabular}

In the present study, it was shown that quality of life was not changed by increasing age or gender in individuals $>65$ years of age, while it was influenced from an educational status and the presence of chronic diseases. The level of depression and pain intensity negatively affected the quality of life.

In conclusion, the presence of chronic diseases, depression, and pain were factors reducing the quality of life in the geriatric population; thus, educational programs aimed at modifying lifestyle and nutritional habits predisposing for chronic disease, depression, degenerative, and inflammatory diseases in these individuals should be provided to the target population by primary health care institutions, as well as written and visual media. Screening programs should be instituted for the early diagnosis of the above-mentioned conditions, and patients should be monitored regularly for treatment compliance following diagnosis. In order to achieve these goals, social security policies should be revised in accordance with the needs of the elderly population and geriatric health centers with qualified staff, including social workers and geriatrists should be established.

\section{Conflict of Interest}

No conflict of interest declared by the authors.

\section{References}

1. Clark GS, Siebens HC. Geriatric Rehabilitation. In: De Lisa J,editor. Physical Medicine and Rehabilitation. Philadelphia,Lippincott Williams Wilkins; 2005. p. 1531-60.

2. Kutsal YG. Yașlanan Dünya.Türk Fiz Tıp Rehab Derg 2006; 52 (Özel Ek A): 6-11.

3. Barker WH. Prevention of disability in older persons. In: RB Wallace, editor. Maxcy-Rosenau-Last Public Health \& Preventive Medicine. 14th ed. NewYork: Appleton Lange; 1998. p. 1059-68.

4. Akdemir N. Yașlılarımızın bakım sorunları ivedilikle çözümlenmelidir. Türk Geriatri Dergisi 2000; 3: 169.

5. Koç I, Hancıoğlu A. Hane halkı nüfusu ve konut özellikleri. Hacettepe Üniversitesi Nüfus Etütleri Enstitüsü. Türkiye Nüfus ve Sağlık Araștırması 2003. Hacettepe Üniversitesi Hastaneleri Basımevi; 2004. p. 17-32.

6. The Whoqol Group. The World Health Organization quality of life assessment (WHOQOL): development and general psychometric properties. Soc Sci Med 1998; 46: 1569-85.

7. De Haes JCJ, Van Knippenherg FCE. The quality of life of cancer patients: a review of the literature. Soc Sci Med 1984; 20: 809-17.

8. Andeston RJ, Schumaher SA, Naughton MJ, Colombo KA. Assessment of health related quality of life in older adults. In: Hazzard RW, Blass JP, Ettinger WH, Holter JB, Ouslander JG, editors. Principles of Geriatric Medicine and Gerontology. New York, Mc Graw Hill; 1998. p. 255-66.

9. Borman P. Yașlılıkta yașam kalitesi. In: Kutsal YG, editor. Temel Geriatri. Ankara: Güneș Tıp Kitabevleri; 2007. p. 1197-201. 
10. Fizpatrick R, Fletcher A, Gore S, Jones D, Spiegelhalter D, Cox D. Quality of life measures in health care. I: Applications and issues in assessment. BMJ 1992; 305: 1074-7.

11. Kaya B. Yașlılık ve depresyon-ı: Tanı ve değerlendirme. Türk Geriatri Dergisi 1999; 2: 72-82.

12. MacDonald AJD. ABC of mental health: Mental health in old age. BMJ 1997; 315: 413-7.

13. Lovestone S, Howard R. Depression in elderly people. London: Martin Dunitz Ltd;1997. p. 80.

14. Dișcigil G, Gemalmaz A, Bașak O, Gürel FS, Tekin N. Birinci basamakta Geriatrik yas grubunda depresyon. Türk Geriatri Dergisi 2005; 8: 129-33.

15. Sütoluk Z, Demirhindi H, Savaș N, Akbaba M. Adana huzurevlerinde kalan yașlılarda depresyon sıklığı ve nedenleri. Türk Geriatri Dergisi 2004; 7: 148-51.

16. Erdoğan S, Candansayar S. Depresyon, Anksiyete ve Yeme Bozuklukları. In: Kutsal YG, editör. Temel Geriatri. Ankara, Güneș Tıp Kitabevleri; 2007. p. 1203-17.

17. Aydemir Ö. Konsültasyon-Liyezon psikiyatrisinde yașam kalitesi ölçümü: Kısa Form-36 (SF-36). 3P Dergisi 1999; 7: 14-22.

18. Koçyiğit H, Aydemir Ö, Fișek G, Ölmez N, Memiș A. Kısa Form-36 (KF-36) 'nın Türkçe versiyonunun güvenilirliği ve geçerliliği. İlaç ve Tedavisi Dergisi 1999; 12: 102-6.

19. Yesavage JA, Brınk TL, Rose TL. Development and validation of geriatric depression screening scale: a preliminary report. J Psychiat Res 1983; 17: 37-49.

20. Sağduyu A. Yașlılar için depresyon ölçeği: Hamilton depresyon ölçeği ile karșılaștırmalı güvenilirlik ve geçerlilik çalıșması. Türk Psikiyatri Dergisi 1997; 8: 3-9.

21. Ertan T, Eker E, Șar V. Geriatrik depresyon ölçeğinin Türk yașlı populasyonunda geçerlilik ve güvenilirliği. Nöropsikiyatri Arșivi 1997; 34: 62-71.

22. Redondo-Sendino A, Guallar-Castillon $P$, Banegas JR, Rodriquez-Artalejo F. Gender differences in the utilization of health-care services among the older adult population of Spain. BMC Public Health 2006; 6: 1-9.

23. Turgul Ö, Mandıracıoğlu A, Özuğurlu B, N Özgener, Deveci $H$. Narlıdere Illçesinde 65 yas üstü nüfusun yașam kalitesinin değerlendirilmesi. İzmir 1. sağlıkta yașam kalitesi sempozyumu 8-10 nisan 2004, poster no: 6 .
24. Cingil D, Bodur S. Huzurevi ve aile ortamındaki yașlıların yașam kalitesi. V. Halk Sağlığı Günleri Bildiri Özetleri Kitabı. Eskișehir 2001. p. 54.

25. Lüleci E, Mandıracıoğlu A. Manisa'da huzurevlerinde yașayan yașlıların günlük yașam aktivitelerinin ve yașam kalitelerinin belirlenmesi. 7. Halk Sağlığı Günleri Bildiri Özetleri Kitabı. Eskișehir 2001. p. 5.

26. Skevington SM, Lofty M, O'Connell KA. The World Health Organization's WHOQOL-BREF quality of life assessment: Psychometric properties and results of the international field trial a report from the Whoqol Group. Qual Life Res 2004; 13: 299-310.

27. Arslantaș D, Metintaș S, Ünsal A, Kalyoncu C. Eskișehir Mahmudiye İlçesi yașlılarında yașam kalitesi. Osmangazi Tıp Dergisi 2006; 28: 81-9.

28. Kuan-Lang L, Rong-Jye T, Bing-Long W, Hong Shen L, Roger LA, Senyeong K. Health-related quality of life and health utility for the institutional elderly in Taiwan. Qual Life Res 2005; 14: 1169-80.

29. Canbaz S, Sunter AT, Dabak S, Peksen Y. The prevalance of chronic diseases and quality of life in elderly in Samsun. Turk J Med Sci 2003; 33: 335-40.

30. Arslan Ș, Gökçe Kutsal Y. Geriatride yașam kalitesinin değerlendirilmesi. Geriatri Dergisi 1999; 2: 173-8.

31. Orfila F, Ferrer M, Lamarca R, Tebe C, Domingo-Salvany A, Alonso J. Gender differences in health-related quality of life among the elderly: The role of objective functional capacity and chronic condition. Social Science\& Medicine 2006; 63: 2367-80.

32. Alonso J, Ferrer M, Gandek B, Ware JE Jr, Aaronson NK, Mosconi $\mathrm{P}$, et al. Health-related quality of life associated with chronic conditions in eight-countries: results from international-Quality of Life Assessment (IQOLA) Project. Qual Life Res 2004; 13: 283-98.

33. Bilir N. Yașlılarda sigara bağımlılığı ile mücadele. Türk Fiz Tıp Rehab Derg 2006; 52(özel Ek A): 47-9.

34. Illhan MN, Maral I, Kitapçı M, Aslan S, Çakır N, Bumin MA. Yașlılarda depresif belirtiler ve bilișsel bozukluğu etkileyebilecek etkenler. Klinik Psikiyatri 2006; 9: 177-84.

35. Copeland JRM, Dewey PA. Yașlılarda depresyon. I Kaplan(çev.). Türk Psikiyatri Dergisi 1992; 3: 3-7. 